\title{
Commemorating Race and Empire during the First World War Centenary
}

Ben Wellings, Shanti Sumartojo and Matthew Graves

Aix-en-Provence / Liverpool : Presses Universitaires de Provence / Liverpool University Press, 2018, 7-20, 2018.

\section{Introduction}

In November 2016, at the halfway point of the First World War Centenary, a modest exhibition based on volunteer research and supported by the UK Heritage Lottery Fund opened in the London suburb of Wood Green. Far from the Western Front presented accounts of South Asian servicemen who served across the many theatres of war. It was only mounted for a few days, but it sought to complicate both the dominant British narrative of the First World War as trench warfare in France and Belgium, and common depiction of the British forces as white. By focusing on the 'untold stories of South Asians whose crucial contribution shaped the First World War' the exhibit sought to remind (or inform) visitors that 'there was more to the First World War than mud and trenches of Europe'. The exhibit rediscovered stories that sought to shift common perceptions of the Great War in England and introduce alternative threats and hardships into the collective memory of the War: 'the threat of lions on patrol in East Africa, thirst in the 50 degree heat of the Sinai desert, and starvation at the Siege of Kut'. ${ }^{1}$

Yet if such broader experiences were common to many millions of people outside of Europe in 1914-18, the representation of this aspect of the Great War was in a decidedly minor key in 2014-18. David Olusoga argues that 'the First World War has a unique characteristic that has - among another consequences - come to submerge the war's multinational, multi-ethnic and multiracial dimensions'. ${ }^{2}$ This book explores why this was the case and engages directly with the question of how race and empire were understood during the war, and how subaltern narratives were recognised, forgotten and commemorated one hundred years later. It shows why and how non-national narratives of region, race and empire were elided, forgotten and occasionally commemorated in particular ways at particular times and in particular places during the First World War centenary.

At its core is the argument that this process of remembering and forgetting has been conditioned in three important ways:

\footnotetext{
${ }^{1}$ See https://southasiansoldiers.org.uk/far-from-the-western-front-the-exhibition/ accessed 28 November 2016.

${ }^{2}$ David Olusoga, The World's War. The Forgotten Soldiers of Empire (London: Head of Zeus, 2014), 39.
} 
1. What gets commemorated and by whom in 2014-18 is significantly conditioned by the demands of the nation-state within the dynamics of the international state system - in this sense commemoration is shaped horizontally;

2. What gets commemorated and by whom in $2014-18$ has already been conditioned by the (mis)representation of subaltern groups during and immediately after the First World War itself - here, historical representation slices vertically through time to shape contemporary commemoration;

3. The 'horizontal' and 'vertical' aspects of contemporary memory and commemoration are complicated by scale of governance at the metropolitan, regional, state and international levels. Scale thus transects commemoration, opening up the possibility of alternative memories at the local and international levels, where they are more able and likely to emerge than at that of the nation-state with its conditioning emphasis on maintaining legitimacy.

Accordingly, this book is organised into three sections that express and support these findings. The first interrogates the contemporary politics of the commemoration of race and empire at the halfway point of the Great War centenary; the second focuses on case studies of the historical antecedents that underlie and shape centennial articulations of race and empire; and the final section analyses some of the monumental structures that exemplify the changing treatment of race and empire over the past century.

\section{National narratives and politics in an international world}

The research presented here reinforces a simple point that bears repeating: that commemorative activity is inescapably political. This fundamental fact is often forgotten amidst the bi-partisan support that war commemoration attracts in liberal democracies. War commemoration is often presented in such democracies as a 'national' activity, therefore free from and 'above' politics. When announcing the UK government's plans for the First World War Centenary at a speech at the Imperial War Museum in London in 2012, for example, British Prime Minister David Cameron said that the centenary should be 'a truly national commemoration' that captured 'our national spirit'. As Andrew Mycock has shown, the word national carried a treble meaning in this context: it meant 'British' rather than any of the other nationalities or ethnic identifications extant in the United Kingdom; it meant Commonwealth as well as UK identifications; but it also signified that this was a 
'national' issue that had been depoliticised before it had been launched. ${ }^{3}$ Similarly, when seeking to introduce the disturbing yet commonplace elements of posttraumatic stress into Centenary commemorations in Australia, historian Bruce Scates was told by one senior public servant that the commemorations should create a 'warm fuzzy feeling' and that the public should not be troubled with tales of suicide and lasting trauma that also formed a part of the war and its lasting aftermath. ${ }^{4}$

However, claiming that commemoration is political is not to deny that this area of public policy is easy terrain for politicians. In November 2013, the already unpopular French President François Hollande was criticised for drawing too direct an analogy between the Union Sacrée of 1914 and the task of economic rebuilding that faced the French people in 2014. ${ }^{5}$ On Remembrance Sunday 2015, the Eurosceptic organisation Leave.EU was heavily criticised for a tweet linking war dead to preserving British freedom and liberties from the European Union. ${ }^{6}$ Although remembrance narratives are deeply national and carry substantial discursive and affective weight, being too overtly partisan is beyond the pale in commemorations.

But it is not this meaning of partisan politics or decisions about the allocations of resources for commemorative activities that is at play during commemorations. Paradoxically, the first element of the political nature of commemorations is that they are deemed apolitical. This is part of the claim that commemorations are 'national'. Scholars of nationalism have noted this equation between claims to a 'national' status and depoliticisation. In this view, as John Breuilly has characterised it, the nation and its past are presented in public discourse as 'something beyond current politics and ideology, as something which is just "there". ${ }^{7}$ But beneath the calm of the commemorative surface, a deeper churn of contestation is taking place. For Ashplant, Dawson and Roper 'the power of dominant memories depends not simply on their public visibility, but also on their capacity to connect with and

\footnotetext{
${ }^{3}$ Andrew Mycock, 'The Politics of the Great War Centenary in the United Kingdom', in Shanti Sumartojo and Ben Wellings, eds., Nation, Memory and Great War Commemoration: Mobilizing the Past in Europe, Australia and New Zealand (Bern: Peter Lang, 2014), 100-07.

${ }^{4}$ Bruce Scates, Laura James and Rebecca Wheatley, World War One: A History in 100 Stories (Melbourne: Penguin Australia), viii.

${ }^{5}$ Michèle Cotta, 'François Hollande à l'épreuve du consensus oublié', Le Point, 8 November 2013: http://www.lepoint.fr/invites-du-point/michele-cotta/michele-cotta-francois-hollande-a-l-epreuvedu-consensus-oublie-08-11-2013-1753464_1595.php accessed 2 December 2016.

${ }^{6}$ Matt Chorley, 'Disgusting! Leave.EU campaign slammed for claiming that staying in the EU threatens the freedoms won by the war dead', Mail Online, 9 November 2015:

http://www.dailymail.co.uk/news/article-3309180/Disgusting-Leave-EU-campaign-slammed-claimingstaying-EU-threatens-freedoms-won-war-dead.html accessed 2 December 2016.

7 John Breuilly, 'Introduction' in Francois Gemenne and Susana Carvahlo (eds.) Nations and their Histories: Constructions and Representations, (Basingstoke: Palgrave, 2009), 18.
} 
articulate particular popular conceptions, whilst actively silencing or marginalizing others' ${ }^{8}$ With regard to war commemoration in particular, they argue that

The primary role of the state in shaping war commemoration highlights its fundamental and politicized role in the formation of national identity in the modern age. War provides a symbolic continuity with the national past, as both fighting and dying for the nation helps to solidify individual and group national identity'. ${ }^{9}$

The salience of war memory in creating and informing a sense of nationhood becomes significant when we link nationality to a way of understanding the social world: in Umut Özkırımlı's words 'a particular way of seeing and interpreting the world, a frame of reference that helps us make sense of and structure the reality that surrounds us'. ${ }^{10}$ John Gillis concurs, arguing that 'identities and memories are not things we think about, but things we think with' ${ }^{11}$ From this premise about the function rather than the form of identity and memory, Gillis concludes that 'Commemorative activity is by definition social and political, for it involves the coordination of individual and group memories, whose results may appear consensual when they are in fact the product of intense contest, struggle and in some cases, annihilation'. ${ }^{12}$

It is this existential quality that gives memory politics its intensity for those seeking to give prominence to their personal or collective remembrance, whilst those who do not have to struggle to make themselves heard are puzzled about why the past should matter so much. If we understand politics to be, in Colin Hay's conceptualisation, as 'the capacity for agency and deliberation in situations of genuine collective or social choice, ${ }^{13}$ then we can see that contestation over memory becomes one means by which to bring collectivities out of the politicalhistorical obscurity and into the realm of public recognition. As discussed in this book, this has real impact in cotemporary identity politics, with commemorative recognition often a part of much larger and more complex histories of racial subjugation or injustice.

\footnotetext{
${ }^{8}$ Timothy Ashplant, Graham Dawson, and Michael Roper, 'The Politics of War Memory and Commemoration: contexts, structures and dynamics' in Timothy Ashplant, Graham Dawson, and Michael Roper, The Politics of War Memory: Commemorating War (London: Routledge, 2000), 13.

${ }^{9}$ Ashplant, Dawson, and Roper, The Politics of War Memory, 22.

${ }^{10}$ Umut Özkırımlı, Contemporary Debates on Nationalism: a Critical Engagement (Basingstoke: Palgrave), 30.

${ }^{11}$ John R. Gillis, 'Memory and Identity: The History of a Relationship' in John R. Gillis ed, Commemorations. The Politics of National Identity (Princeton, NJ: Princeton University Press, 1994), 5.

12 Gillis, The Politics of National Identity, 5.

${ }^{13}$ Colin Hay, Why We Hate Politics (Cambridge: Polity Press, 2007), 77.
} 
Furthermore, the politics that underlie the shape and form of commemorations are not reserved to the domestic sphere, but can also play out as a form of foreign policy (as 'second track' or 'cultural' diplomacy) and operate in this way as an element of international relations and global politics. The French policy of 'Shared Memory' illustrates this international element of the organisation of commemorative events at the international and national scales.

In its first phase 2003-06, the 'Shared Memory' policy emphasised bilateral international ties, in principle with former allies or adversaries who shared a military history with France since 1870. In practice, the first eight agreements were signed with Commonwealth and Cold War allies (Australia, the United Kingdom, New Zealand, Canada and South Korea) and former colonies (Morocco, Tunisia, Madagascar). The declared objective was to enhance shared memorial heritage on French soil. The consecration of a new Commonwealth War Graves Commission (CWGC) cemetery for the Australian and British unmarked graves discovered at Fromelles in July 2010 was one tangible outcome of this foreign policy.

In a second phase, which began with the first international summit on shared memory in 2006, the policy took a multilateral turn intended to 'reinforce the links between states in the field of war memory'. ${ }^{14}$ The UNESCO meeting drew together twenty-four countries, including six from the Commonwealth, to promote a youth agenda, work towards the recognition of colonial veterans' pensions rights, and agree to a biennial calendar of meetings. In the run up to the centenary, this bilateralism laid the basis for what was intended as the 'Europeanisation' of Great War memory at a summit of the Council of Europe presided over by France on 10 November 2008, including the adoption of European symbols in the commemorations and the integration of First World War memory in national history syllabuses. The culmination of French initiatives came with the first of the interministerial meetings in Paris on 17-18 October 2013 where representatives of thirty governments began the preparation and coordination of the Great War centenary calendar under the twin themes of the reconciliation of peoples and the dialogue of national histories.

While it can claim to have been a diplomatic success as a policy, shared memory has failed to convince as an historiographical concept. For Annette Becker, countries such as France and Germany cannot be said to share the same memories even when their war histories coincide, nor do the regions of France; there is little in common about the way the First World War is remembered in the Midi, Alsace or in Paris:

\footnotetext{
${ }^{14}$ UNESCO, 'Premières rencontres internationales sur la mémoire partagée’, UNESCO, Paris, 26-27 October 2006.
} 
Europeans shared in mourning the dead, the lives destroyed and the loss of illusions. But beyond that, the memory of the war was built differently from country to country. There is absolutely no shared memory between the warring nations, and sometimes not even within the countries themselves...Even in a country like France there is no single memory, so imagine the differences between the wars winners and losers. ${ }^{15}$

Building a European-wide memory of the First World War on a conceptually flawed foundation remained problematic. Jean-Jacques Becker points out that Armistice Day does not have the same significance for France and for (most of) the rest of Europe where ' 11 November is not the end of the war, but the beginning of the storm'. ${ }^{16}$ Nevertheless, on 28 February 2012, the French parliament persisted in the conflation of modern war memories by transforming the Armistice into a homage to all those who have died in war for France.

Beyond Europe, with its advanced mechanisms of policy sharing, a conscious reworking of deliberately forgotten pasts has been evident. Such a process of rediscovery and rehabilitation was observable in the People's Republic of China (PRC). The 'real and discursive boundaries' that Elizabeth Rechniewski noted applied to tirailleurs sénégalais applied equally to the experience and memory of Chinese labourers on the Western Front. The employment of Chinese labour from 1916-20 was a product of the new Chinese Republic's (unsuccessful) attempts to shape the outcome of the post-War period in East Asia. ${ }^{17}$ After the war and reconstruction the majority of the estimated 135, 000 labourers from Shandong province returned to China, but after the Communist victory in 1949 these labourers became an embarrassment to the Communist Party because they had worked for Western Imperialists. ${ }^{18}$ However, as Paul Bailey shows in Chapter 2, once the post-Mao era of economic reform had stabilised, the People's Republic of China rehabilitated Chinese labourers from the First World War not as 'coolies' in the service of western imperialism but as trans-national agents in the service of China, this bringing them back from post-1949 obscurity.

The memory of the First World War in India has gone through another observable if modest - rehabilitation, although for different reasons to China. In India the ideology from which the memory of Indian participation needed to be rescued was

\footnotetext{
15 'The Sundaily, 'The historians view: why no shared memory of Great War', The Sundaily, Sun Media Corporation Malaysia, 5 March 2014: http://www.thesundaily.my/news/969181 accessed 3 November 2014.

${ }^{16}$ Jean-Jacques Becker, L'Europe dans la Grande guerre (Paris : Belin, 1996), 244.

${ }^{17}$ Adam Tooze, The Deluge. The Great War and the Remaking of the Global Order (London: Penguin, 2014), 100.

${ }^{18}$ Mark O'Neill, The Chinese Labour Corps. The Forgotten Chinese Labourers of the First World War (London: Penguin, 2014), 1.
} 
nationalism rather than communism. Not unlike the trajectory of forgetting and remembering participation in the Great War in Ireland, the considerable contribution to winning the war that came from British India was pushed into obscurity by the demands of nationalist memory after 1947. This ideational occlusion was compounded by further political complications, the military confrontations between India and Pakistan since independence not least amongst them. But despite the difficulty in gaining access to lieux de mémoire such as the war memorial in Basra, the sensitivity towards Christian war cemeteries in Pakistan and the destruction or initially incomplete records of the British Indian Army, Peter Stanley argues in Chapter 3 that a rehabilitation of Indian soldiers is taking place in India. This intersects with the memory of the conflict in the United Kingdom where South Asian communities are encouraged to seek out familial links with the war and where the CWGC memorial at Neuve Chappelle has been the site of commemorative diplomacy by Indian Prime Minister Narendra Modi. In comparison with commemorations in Europe, the examples from what used to be British India highlight the importance of 'memorial diplomacy' in facilitating the beginnings of a shared memory. ${ }^{19}$ In the context of fluctuating international relations such as those between India and Pakistan, or the instability in Basra leading to the relocation of a significant memorial, 'shared memory' - with all its limitations - cannot even begin to take root, leaving First World War memory in the Indian sub-continent permanently partitioned.

The re-emergence of the traces of memory associated with race and empire occurred in a historical shift to re-legitimise empire after the end of the Cold War and during the 'War on Terror/Long War' in the developed world. This was accompanied by the emergence of China and India as global powers with concomitantly global agendas. However, if both China and India can bring considerable resources to bear to push memory of their contributions to the Great War into the realm of international public diplomacy the same cannot be said for the Congo. Although, as Laurence van Ypersele and Enika Ngongo demonstrate in Chapter 4, it played a significant part in Belgium's war, the lack of a Congolese presence in the European theatre meant that they have been little remembered in the Belgian First World War centenary commemorations. Keith Jeffery has described what he calls a 'remembrance deficit' in Africa that is not just related to material resources, but also to the forgetting of African contributions by the imperial powers during and immediately after the War. As in British India, a racial hierarchy in death meant - certainly in the British case - that porters and askari were rarely recorded

\footnotetext{
${ }^{19}$ Matthew Graves, 'Memorial Diplomacy in Franco-Australian Relations', in Shanti Sumartojo and Ben Wellings, eds, Nation, Memory and Great War Commemoration: Mobilizing the Past in Europe, Australia and New Zealand (Bern: Peter Lang, 2014), 169.
} 
by name and usually accorded mass graves. ${ }^{20}$ For van Ypersele and Ngongo a combination of administrative division of commemorative organisation combined with the historical conditioning of Belgian colonial memory has created this absence in Belgium's centenary commemorations. The international organisation of commemorative activity was the responsibility of the Belgian federal government, and relations with the Congo were not strong following the rapid decolonisation of the vast central African country in 1959-60. Despite the work of a small but growing diaspora of Congolese people in Belgium to insert remembrance of the war in Africa into the commemorative programme, the contribution of Belgium's African colony remained largely forgotten in 2014-18.

A slightly different picture emerges from Aotearoa/New Zealand. Katherine Smits shows in Chapter 5 how opinion amongst Maori iwi (tribe or people) was divided during the War as to whether or not to fight for the British, although a Maori battalion was eventually raised. The debate at the time was whether or not to fight for the people against whom Maori had been at war in living memory, and who had dispossessed those iwi of their lands, leaving them with both Maori and British kings but no country. ${ }^{21}$ A further complication stemmed from the debate over whether Maori should fight or whether their principal contribution should consist of labour and ceremonial duties performing the haka. Ultimately the Maori Pioneer Battalion raised for the duration allowed some Maori to rediscover a warrior tradition in a period of increasing marginalisation within settler New Zealand society. The significant divisions amongst Maori during the First World War found resonance in post-imperial Aotearoa/New Zealand over issues of sovereignty and representation, difficult issues in a settler society like New Zealand, unlike India and Congo where the imperial powers and their colonists departed. Such issues were overlooked in centennial commemorative activities in Aotearoa/New Zealand due to the need to present a bicultural logic of post-imperial New Zealand nationhood. In this way, Maori and Pakeha struggled with an over-supply rather than a deficit of memory, and an official imperative to create unity out of a history of division. First World War commemoration here had the effect noted by Ashplant, Dawson and Roper of marginalising and obscuring narratives that do not align with those of the primary power holders, in this case the bicultural nation-state.

From this evidence we can conclude that the nation-state - the principal organisation with authority to coordinate national and international commemorative events - finds it challenging to commemorate the dissonance and dissidence that the memory of racism and imperialism pose to legitimising contemporary national

\footnotetext{
${ }^{20}$ Keith Jeffery, 1916. A Global History (London: Bloomsbury, 2015), 240-1.

${ }^{21}$ Philippa Mein Smith, A Concise History of New Zealand, 2e (Cambridge: Cambridge University Press, 2012), 139.
} 
narratives such as biculturalism or multiculturalism. This should not, however, be seen as a simple case of deliberate forgetting. Instead it is related to the way that race and empire - crucial elements in the prosecution and organisation of the First World War - had already been misrepresented, hidden and forgotten one hundred years ago during the conflict itself. This initial physical and ideational containment of race and empire in the metropole was compounded because as organisational concepts they were de-legitimised in the post-colonial era that began during the First World War and reached fruition after the Second.

\section{(Mis)representing race and empire, 1900-20}

Although they were hard to discern in contemporary commemorative activities, race and empire were major organisational ideologies at the time of the First World War. Race, as David Olosuga has shown, determined who could fight and where they could fight. ${ }^{22}$ The 1914-18 fighting in Europe was as 'white man's war' with three important exceptions. The first of these were the so-called Martial Races of the British Empire, men drawn from the northern parts of British India, but also Maori from New Zealand, who fought in France and Belgium. The second was the Force Noire composed of tirailleurs sénégalais and North African Troops who fought in France. A third group were African-Americans who came to France after the USA entered the war in 1917, some of whom were integrated in French fighting units.

The deployment of these troops was very controversial at the time, amongst French and British populations as much as their German adversaries. This century old controversy is one of the first reasons that race and empire are difficult to incorporate into acts of remembrance and commemoration in the 2014-18 period. Elizabeth Rechniewski demonstrates in Chapter 6 how troubled authorities were during the First World War about the effect that being in France might have for the colonial order in French West Africa when the tirailleurs sénégalais eventually returned home. These fears also turned on concerns about exposure to white French women during periods of convalescence of hivernage (billeting for colonial troops in the warmer south because they were felt to be unsuited to the winters of northern France) as well as the corrosive effects on white authority brought about by fighting other whites (Germans) in the trenches of the Western Front. As Rechniewski argues, the official response was to hide these troops as much as possible, both physically and discursively, which had the effect of consigning them to a 'long-forgotten corner of French social and military history'.

Not all discourses of race in 1914-18 concerned non-white peoples, as the interest in Australian and South African fighting men arriving in Marseilles showed. Deirdre Gilfedder points out in Chapter 7 that race was a crucial element shaping the

\footnotetext{
${ }^{22}$ Olusoga, The World's War, 53-62.
} 
thoughts and actions of journalists Charles Bean and Ellis Ashmead-Bartlett, both of whom helped create fundamental elements of what in 2014-18 was remembered as a foundational moment in Australian nationhood. The idealised image of the Anzac that they crafted was heavily influenced by (positive) eugenic thinking whereby the Australian environment created 'a new, strange race'; or rather a new, robust subspecies of the British race. In this case, what was understood on the outbreak of the First World War as the influence of racial development helped create national distinctiveness, yet that also bound Australians to Britons through hereditary ties [ref chapter]. In these ways the memory traces of race and empire lived on during the First World War centenary, unwittingly borne down the years by the continuity present in Anzac commemoration. ${ }^{23}$

Yet this official concealment had to contend with popular interest in (and at times confusion over) the presence of such colonial troops. Gilles Teulié's research into postcards as 'memory traces' reveals this fascination and confusion (see Chapter 8). Teulié estimates that 2.2 million postcards were published in France in 1914, making them a highly important medium for communicating images of the war and especially foreign troops. It is such a medium that acts as what he calls 'the first circle of memory'; images that are deemed commercially successful, and are then transmitted and occasionally preserved until the present day. The postcards that have survived from Marseilles in 1914-18, the disembarkation point for nonEuropean arrivals from Asia, Africa and Australasia, demonstrate a fascination with what were referred to at the time as 'Indoo' troops (a collective term often used for troops from British India whatever their religion). But they also reveal confusion, with South Africans labelled as Scots (probably because of the kilts worn by South African Scottish regiments) and less explicably Ghurkhas labelled as 'Canadiens'. This shows that popular local knowledge of other empires was partial and being formulated through the colonial contact generated by the First World War.

A second example of colonial contact afforded by the Great War was the official use of images of empire for recruitment purposes. In the era of high imperialism that we associate with the Partition of Africa and imperialist interventions in China, Korea and the Philippines, not everyone was agreed that such expansion was a good idea. Empires may have been acquired in 'a fit of absence of mind', but what were they for? The outbreak of war in 1914 provided a compelling answer to this question: the Empire would aid the Mother Country. In Chapter 9, Cherie Prosser shows that representations of colonial troops on recruitment posters served a double purpose: they sought to increase enlistment from the colonies when the huge losses required more and more men to join the armed forces of Britain and France; and they sought to reassure British and French citizens that their respective Empires were united

\footnotetext{
${ }^{23}$ Carolyn Holbrook, Anzac. The Unauthorised Biography (Sydney, New South, 2014), 144-45.
} 
behind the cause. Although nationalist movements really gained strength in British India and North Africa after the conclusion of hostilities, the loyalty of the colonies could not be taken for granted, as the Germans and Ottomans tried to exploit. ${ }^{24}$ Prosser argues that these geostrategic considerations had the effect of reducing the representation of colonial troops to a collection of stereotypes. This in turn supported the creation of the illusion of cohesion in the French and British metropole and beyond to the colonies themselves. In the case of British India these ultimately unhelpful stereotypes created unrealistic expectations about loyalty in the colonies that ultimately undermined the imperial endeavour in the inter-War years. $^{25}$

In the cases of the (mis)representations of the tirailleurs, the imperial troops arriving in Marseilles, the stereotypes conveyed via recruitment posters and the eugenicist elements of the Anzac legend helped create the structures of memory at the moment of their creation that subsequently occluded the contribution of subaltern groups or shaped collective remembrance thereafter. This suggests that one explanation for the predominant 'whiteness' of the 2014-18 centenary commemorations in Western states is a product of the organising power of race that was dominant in 1914-18.

\section{Entanglements of scale: shared memories and memorialisation}

This is not to suggest, however, that race and empire were totally excluded from centenary commemorations. But the 'horizontal' and 'vertical' structures of political and historical power shaping collective memory and remembrance did have an effect on where race and empire were commemorated and in what form. One way to understand how the rehabilitation of race and empire in First World War commemorations pushed against the unifying nation-state narratives in major events, is to consider the different scales of remembering and forgetting. Throughout the chapters in this book, political and bureaucratic power at local, metropolitan and regional scales all either legitimise the nation differently, or do not feel the need to legitimise it at all. As a result, commemoration of race and empire has emerged in ways that can complicate or even pull against state-level activities.

Discourses of race and nation and questions concerning the operation of power and legitimacy at national and international levels shape memory of the First World War. But these ideational elements must be enacted and made concrete locally with the support of municipal and regional government seeking to put a distinctive stamp on

\footnotetext{
${ }^{24}$ Eugene Rogan, The Fall of the Ottomans. The Great War in the Middle East, 1914-20 (London: Penguin, 2015), 70-74.

${ }^{25}$ Bernard Porter, The Lion's Share. A Short History of British Imperialism, 1850-1995, 3e (Harlow, Longman, 1996), 263.
} 
national and international commemorations. The history of the First World War in Marseilles, the gateway to France and the Western Front for many Allied troops, and the contemporary commemoration of that history, exemplifies the conceptual framework outlined so far, and highlights the importance of considering scale.

In 2015, a Great War centenary exhibition at the Marseilles city archive called 'Marseillais fait ton devoir'! opened its doors. That exhibition was just one of a constellation organised by the cities of France behind the lines of the Western Front from 2014 under the aegis of the Mission du Centenaire in concert with local, departmental and regional government agencies, museums, archives and memorials. The exhibit drew on the substantial private collections of souvenirs and mementoes acquired by the municipal archives, including Australian press reports of the arrival of the ANZAC troops in France in the spring and summer of 1916. Marseilles was described as a city at the crossroad of empires, 'where races meet to defend France'. In its crowded streets, French civilians rubbed shoulders with Ghurkhas, 'Indians', South Africans, Australians, Senegalais and Tonkinois, as well as German prisoners and refugees from the Balkans who make up a 'jostling, heterogeneous crowds' in a city 'which feels much closer to the fighting line...than in Paris'. ${ }^{26}$ The city was presented as a meeting place of East and West and under the heading 'Prejudices broken down', an Australian journalist drew a moral from its example:

A national calamity has broken down the century-old barriers of distrust and misunderstanding. The mother country knows and appreciates the self-sacrifice of her distant possessions, while the Australians in their turn have come to realise the difficulties and racial prejudices suffered by those at home. ${ }^{27}$

That the influx of hundreds of thousands of colonial and allied troops during the Great War posed fundamental questions about race relations to contemporary observers, both at home and abroad, is an aspect of Marseilles' wartime record that was largely neglected in English language histories until the publication of David Olusoga's study of the conflict's 'forgotten soldiers', The World's War (2015), which described how Marseilles was 'shaken from its peacetime slumber to become a great garrison city in which the tribes of empire were gathered for war' ${ }^{28}$

In addition to contemporary reports in the French and British press of the patriotic fervour which greeted the newcomers, propaganda material in the municipal and departmental archives suggest that the exoticism of the soldiers of empire was actively promoted as a civilian morale booster. This material includes a series of

\footnotetext{
26 'Marseilles: Where Races Meet to Defend France', Camperdown Chronicle, 6 July 1916, 6.

${ }^{27}$ Camperdown Chronicle, 6 July 1916, 6.

${ }^{28}$ Olusoga, The World's War, 41.
} 
information booklets on the allied armies; postcards of colonial and dominion troops parading through Marseilles; a fold-out poster map of the British Empire and its contribution in manpower and capital to the war effort; the publication in English translation of the Franco-Russian artist Massia Bibikoff's diary-cum-sketchbook of the British Indian army divisions in their city encampments, ${ }^{29}$ and the postcards analysed by Giles Tuillé noted above. The captions accompanying the images of 'our Allies in Marseilles' were explicit: France does not fight alone; the Force noire of the French Empire and the 'martial races' of the British empire have rallied to the nation's aid; the poilu or citizen-soldier is backed by the volunteers of the Italian Garibaldi and Greek émigrés brigades assembled in Provence in defence of the Republic before Greece and Italy even entered the War.

Despite this vibrant history, public interest in 2014-18 centenary events in Marseilles was muted if not disappointing; perhaps in part because regional memory is the less visible underside of national and international commemorative programmes, at a remove from the tribunes of memorial politics and diplomacy, and as such at odds with the policy of 'shared memory' promoted by France since 2002, as noted above. Even within the nation-state itself, memories clash and jar between the core and the periphery: the opening of hostilities in 1914 is chiefly remembered in the Midi for the humiliation of the soldiers of the XV Corps, unjustly accused of deserting the battlefield in Lorraine. ${ }^{30}$ The sole Commonwealth commemorative ceremony of note to be held in Marseille by the end of 2016 was a reconstitution of the landing of the Sikh soldiers of the Lahore and Meerut divisions at the Monument aux Héros de l'Armée d'Orient on 26 September 2014 by the Representative Council of French Sikhs, occupying the place left vacant by the Indian government's reluctance to engage in commemorations associated with the era of British rule in India. ${ }^{31}$ As such, it marked a communitarian rather than a national memory.

But it is from between the cracks in national and international commemorative activity that subaltern memories emerged. The politics of commemorating race and empire takes on a completely different shape and impact when considered at the local, metropolitan, or regional scale. By shifting away from the nation-state with its imperative to seek legitimacy as the dominant power holder in shaping commemorative events, the local and regional levels opened up new opportunities for commemorative expression.

\footnotetext{
${ }^{29}$ Massia Babikoff, Our Indians at Marseilles (London : Smith, Elder \& Co., 1915).

${ }^{30}$ Jean-Yves Le Naour, 'La faute aux 'Midis': la légende de la lâcheté des méridionaux au feu', Annales du Midi, October-December (2000), 499-515.

31 'Conseil Représentatif des Sikhs de France, Commémoration du Centenaire de l'Arrivée des Soldats Sikhs en France', 25 September 2014: http://www.sikhsdefrance.fr/commemoration-du-centenairelarrivee-soldats-sikhs-en-france/ accessed 12 February 2015.
} 
War memorials, for example, lie at the intersection of the national and the local and are widespread in both cities and rural battlefield sites. ${ }^{32}$ Yet this growth of memorials was not confined to Europe alone; indeed the selection and construction of memorials are even more complicated outside of Europe itself. All these currents of history and ideology are set out and contested at different scales through attempts to memorialise race and empire in the context of shifting understandings of conflict in settler societies. The rehabilitation and rediscovery is far from uncontroversial and often fiercely contested. As Liz Recniewski has shown, the existence of a First World Memorial in Kone, New Caledonia was cross-cut by memory of a revolt by indigénes in 1917 and became contentious again in the context of (long-standing) plans for the devolution of power from France. ${ }^{33}$ Dónal Hassett has shown in Chapter 10 how the post-colonial Algerian state literally concreted over First World War memorials in Algiers and Oran, thus occluding, but not completely erasing, the previous narrative of settler-indigenous brothers-in-arms and common endeavour with a post- and anti-colonial nationalist memory.

Drawing evidence from Australia, Ben Wellings and Shanti Sumartojo build their analysis of the politics of memorialisation on the related but distinct concepts of soldier and warrior, war and conflict, and the differing interpretations of the past that these concepts implied (Chapter 11). Analysing the place of Indigenous Australians in First World War commemorations, they find that differing memorial expressions of the past have emerged at difference scales of governance. The memory of settler-indigenous conflict means that indigenous memorials were too historically freighted to be placed in nationally symbolic sites like the Australian War Memorial in Canberra. Yet although remaining controversial, the commissioning and placing of memorials by city governments in urban locations was more frequent and less contested between 2013-16.

The nation-state - the principal organisation with authority to conduct the national and international coordination of commemorative events - found it challenging to commemorate the dissonance and dissidence that the memory of racism and imperialism pose to legitimising contemporary national narratives such as biculturalism in Aotearoa/New Zealand or multiculturalism in Australia. However, because metropolitan governments are not as heavily invested in the legitimacy of the nation, memorials displaying broader intersections with indigenous memories of conflict, dispossession and war were built in Adelaide, Sydney and Melbourne. It

\footnotetext{
32 Jay Winter, Sites of Memory, Sites of Mourning. The Great War in European Cultural History (Cambridge: Cambridge University Press, 1995), 79.

${ }^{33}$ Elizabeth Rechniewski, 'Contested Sites of Memory: Commemorating Wars and Warriors in New Caledonia' in Shanti Sumartojo and Ben Wellings, eds., Nation, Memory and Great War Commemoration: Mobilizing the Past in Europe, Australia and New Zealand, (Bern: Peter Lang, 2014), 189-204.
} 
was at this scale that subaltern narratives were able to emerge and complicate dominant national-level narratives conditioned by the demands of the international system and the racialised memories with their roots in 1914-18.

\section{Conclusions: variable geometries of remembrance}

While the internationalisation of Great War commemoration and its 'shared memory' has been assiduously pursued since 2002, never more dramatically symbolised than by the 72 combatant nations assembled on the Champs Elysées for the Bastille Day parade 2014, regional divergences reveal a memory of the First World War that is much more complex and contradictory. ${ }^{34}$ Reading the centenary through the prism of 'memory from below', as Rémi Dalisson calls it - forms of remembrance from below or from the periphery, from behind the front lines and far from the zones of combat - decentralises national memory in a way which allows subaltern histories to resurface: those of the 'forgotten soldiers' of the French and British empires and the stark contrasts in their treatment; of the Chinese, Indian, Egyptian and Fijian labourers whose histories have begun to be recovered by the likes of Paul Bailey, Peter Stanley, David Olusoga and Li Ma. ${ }^{35}$ It exposes variable geometries of remembrance, underscored by regional disparities, and underwritten by the continuities and discontinuities in the national histories of the winners and losers, the colonial and postcolonial states.

Thus, as we have argued in this chapter, the process of (mis)representing, remembering and forgetting race and empire in the First World War centenary has been conditioned in three important ways. The first is that what was commemorated and by whom in 2014-18 was shaped by the demands of the nationstate within the dynamics of the international state system, including through processes of 'memorial diplomacy', in a 'horizontal' analytical axis. Secondly, centenary commemorations were strongly shaped by initial (mis)representation of subaltern groups during and immediately after the First World War itself; this legacy of attitudes towards race and empire handed down as memory and history can be thought of as a 'vertical' element in the analysis. Thirdly, the 'horizontal' and 'vertical' flows of memory and commemoration in 2014-18 were complicated and transected by scale in metropolitan, regional and international levels of governance; and activities at these scales allowed alternative memories to emerge more readily that at the level of the nation-state. In the chapters that follow, these arguments will be exemplified and deepened by a wide range of new research on the First World War, its impact and commemoration, and the ongoing role it plays in contemporary society and politics.

\footnotetext{
${ }^{34}$ Rémi Dalisson, Histoire de la Mémoire de la Grande Guerre (Paris : Editions Soteca, 2015), p.209.

${ }^{35}$ Li Ma, Les travailleurs chinois en France dans la Première guerre mondiale (Paris : CNRS, 2012).
} 